\title{
Erratum: Elastic spheres can walk on water
}

\author{
Jesse Belden, Randy C. Hurd, Michael A. Jandron, Allan F. Bower \& Tadd T. Truscott
}

Nature Communications 7:10551 doi: 10.1038/ncomms10551 (2016); Published 4 Feb 2016; Updated 10 Jun 2016

This Article contains an error in Fig. 5 that was introduced during the production process. The coloured background is scaled incorrectly relative to the axes and foreground figure elements. The correct version of Fig. 5 appears below.

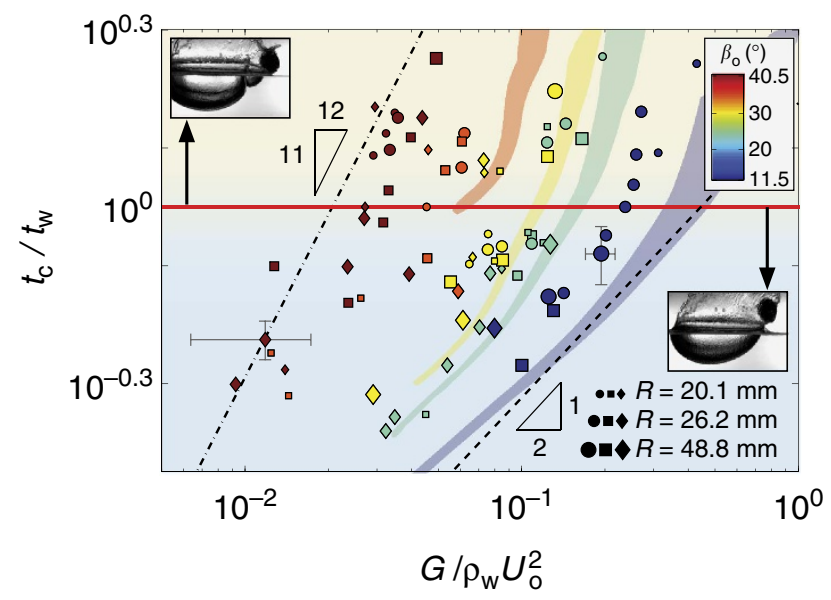

Figure 5

(c) (i) This work is licensed under a Creative Commons Attribution 4.0 International License. The images or other third party material in this article are included in the article's Creative Commons license, unless indicated otherwise in the credit line; if the material is not included under the Creative Commons license, users will need to obtain permission from the license holder to reproduce the material. To view a copy of this license, visit http://creativecommons.org/licenses/by/4.0/ 